補経誌，J Jpn Prosthodont Soc, 40：122～132, 1996.

原著論文

\title{
顎関節内障における顎関節腔内病変と顎運動の 関連性に関する研究
}

\author{
細田＼cjkstart裕
Comparative Study between Mandibular Tracking Patterns and Morbid Intra Articular Changes of the TMJ Internal Derangements

Yutaka Hosoda

\begin{abstract}
Thirty-five patients with internal derangement of the temporomandibular joint who had unilateral anterior disc displacement without reduction were studied. The patients were classified according to the degree of disc displacement and the presence or absence of an abnormal disc configuration on magnetic resonance imaging (MRI). Arthroscopic examination of the upper joint compartment was also performed, and intra-articular changes on the disc surface, the articular surface of the temporal bone (load-bearing areas) and the synovial lining (a load-free area) were classified. The findings were compared with the corresponding mandibular tracking patterns to study the association between these factors. The results were as follows :

1. There was no discernible relation between the mandibular tracking patterns and the disc conditions (degree of disc displacement and disc configuration on MRI).

2. An analysis of the arthroscopic findings of the upper joint compartment and the corresponding mandibular tracking patterns revealed no distinct relation between the mandibular tracking patterns and morbid findings of the articular surface of the temporal bone and disc surface. However, there was a significantly increased incidence of decreased range of opening motion $(p<0.05)$ and unstable maximum opening position $(p<0.01)$ among patients with evidence of fibrous adhesion of the synovial wall, especially at the anterolateral portion of the upper joint compartment, and those with fibrosis of the synovial wall.
\end{abstract}

Key words : temporomandibular joint, internal derangement, osteoarthrosis, mandibular tracking, arthroscopy

\section{I. 緒 言}

顎関節内障は下顎頭および側頭骨に対する関節円板の相 対的位置異常に起因する顎機能異常と定義されてい $ろ^{1,2)}$. これは顎機能異常患者の顎運動, 特に矢状方向の 下顎頭運動と, その関節腔造影X線写真との対比によって

鶴見大学大学院歯学研究科歯科補緅学専攻（指導：福島俊士教授） The Second Department of Prosthetic Dentistry,Tsurumi University School of Dental Medicine (Director : Prof. Shunji Fukushima)

平成 7 年 9 月 6 日受付
明らかとなったことである ${ }^{3,4)}$.

顎関節内障患者に高い頻度で認められる開口制限をはじ めとする種々の運動制限は, 患者の日常生活への影響が大 きく，できるかぎり早期の解除あるいは緩解が望まれる. 運動制限の原因としては，まず前方に転位した関節円板に よる下顎頭運動の直接的な阻害が考えられる.このため, 関節円板の動態と顎運動との関連が追究された.すなわ ち, 関節腔造影検査 ${ }^{5,6)} \mathrm{MR}$ 画像検査 ${ }^{7,8}$ により, 関節円 板の転位の程度や関節円板の変形の様子を明らかにしたの ち, それらの所見と顎運動との関連が検討された．その結 果, 運動制限の原因が転位した関節円板にあると思われる 
場合もあったが，他の因子が原因と思われる場合もあり， より詳細な検討の必要性が示された.

そこで, 本稿では顎関節内障に伴う顎関節腔内病変（以 後, 腔内病変と略す）の存在と䫟運動経路との関連性につ いて検討することにした。これは，䪽関節内障では関節円 板の転位や変形のみならず, 関節内の荷重負担部である関 節面軟骨被覆部や, 非荷重負担部である滑膜被覆部に種々 の病変が出現することが知られており昂10)，そうした病変 の存在は下罘頭運動, ひいては切歯部における顎運動と関 連があると考えられるためである.

\section{II. 研究方法}

本研究では片側性の非復位性関節円板前方転位症例にお けるMR 画像所見および関節鏡視所見と䫟運動との関連 を検討したが, 研究は通常の診査, 診断, 治療の流れのな かで行った。

まず受診患者のうち顎関節内障の疑われた患者につい て, MR 画像検査を行い, 片側性の非復位性関節円板前方 転位症例を選択した。次に,これらの患者について顎運動 を記録した。さらに治療方法の選択のため関節鏡視検査を 行った.この結果に基づき患者に対してパンピング・マニ ピュレーションあるいは関節鏡視下剝離授動術を施行し た.

\section{1. 対象患者}

1994 年 2 月より 1995 年 6 月までの間に, 鶴見大学歯学 部附属病院補緅科および横浜労災病院歯科口腔外科を受診 した頑関節症患者のうち，MR 画像検査により片側性の非 復位性関節円板前方転位と診断した症例で, 上関節腔内の 関節鏡視検查を施行した 35 例を対象とした。

対象患者の性別は男性 1 例（3\%），女性 34 例（97\%） であった。年齢は 15〜62 歳で平均 32.9 歳であった。病悩 期間は $1 \sim 18$ 力月で, 平均 7.2 力月であった。顎関節の機 能時疼痛は 35 例中 29 例（83\%）に認められた。なお咀嚼 筋 spasm および開閉口筋群の圧痛および自発痛が著しい 症例は除外した。

\section{2. 検査項目}

1) MR 画像検査

MR 画像装置は, 日立メディコ社製 MRP-7000 0.3 T (鶴見大学歯学部附属病院) と GE 社製 Signa-advantage $1.5 \mathrm{~T}$ (横浜労災病院) を使用した. 撮像条件は, MRP7000 では SE 法 FOV $12 \mathrm{~cm} / \mathrm{TR} 500 \mathrm{msec} / \mathrm{TE} 38 \mathrm{msec} /$ NEX 3/matrix $240 \times 256$ であり, Signa-advantage では 高速 SE 法 FOV $12 \mathrm{~cm} / \mathrm{TR} 800 \mathrm{msec} / \mathrm{TE} 26 \mathrm{msec} / \mathrm{NEX}$ $2 /$ matrix $256 \times 256 / \mathrm{ETL} 2$ とした。矢状断方向では開口

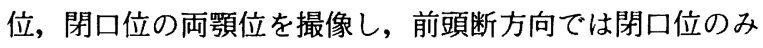
とした.

関節円板の転位の程度は軽度, 中等度, 高度に, また関 節円板形態は変形なしとありに分類した（表 1$)$.

2) 関節鏡視検查

顎関節上関節腔について，外側穿刺による鏡視を単一あ るいは複数外套管穿刺により行った。

関節鏡はメディカルサイエンス社製 FV-2000 E（鏡体 外径 $0.8 \mathrm{~mm}$, ファイバースコープ, 視野角 $50^{\circ}$ ) とスト ライカー社製 TMJ Miniscope（鏡体外径 $2.5 \mathrm{~mm}$, ロッ ドレンズ鏡, 視野角 $0^{\circ}$ ）を使用した. 所見の記録はビデ オレコーダにて行った。

関節鏡視所見の記載は近藤らの分類 ${ }^{12)}$ に準拠し，側頭骨 関節隆起関節面, 関節円板表面および滑膜被覆面の 3 部位 についてそれぞれ行った（表 2 , 図-1 a〜f). 関節鏡視所 見は同一部位において複数の異なる所見が出現した場合に は, 原則として, より進行した病的所見の 1 つをその部位 の代表とした，滑膜被覆面においては線維性癒着，滑膜壁 線維症および滑膜過形成を非可逆的器質的変化と考え病変 ありに分類した．本稿では滑膜の血管拡張所見については 可逆的変化と考え病変なしに分類した. 関節隆起関節面と 関節円板表面では線維化以上を関節面変性所見とし, 病変 ありに分類した。

3）顎運動検査

前頭面における切歯点の限界運動を東京歯材社製サホン ビジトレーナーMedel 3 を用いて記録した。

（1）被検運動（図 2)

被検運動は, 古屋の方法 ${ }^{13)}$ 参考として, まず開閉口運

表 1 Classification of MR images MR 画像所見の分類

\begin{tabular}{|c|c|}
\hline \multicolumn{2}{|c|}{ 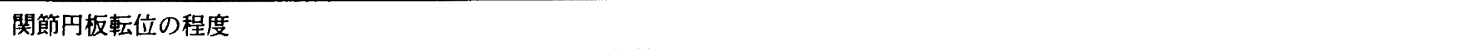 } \\
\hline 軽度 & 関節円板後方肥厚部が下額頭関節面に一部接しているもの. \\
\hline 中等度 & 下額頭関節面に関節円板が接しておらず関節隆起後斜面に関節円板中央狭窄部が位置するもの. \\
\hline 高度 & 関節円板中央狭窄部が関節結節最下方点にあるか，それ以上前方に位置するもの. \\
\hline \multicolumn{2}{|c|}{ 関節円板形態11 } \\
\hline 変形なし & 関筋円板後方肥厚部, 中央狭窄部, 前方肥厚部が明膫に識別できる biconcave を正常形態とし,「恋形なし」とした. \\
\hline 変形あり & $\begin{array}{l}\text { biconcave 以外の } 3 \text { 形態（関節円板が均等な厚さとなり，全体的に厚みを隇じた biplaner 形態，関節円板後方肥厚部 } \\
\text { の厚みが増加した enlargement of posterior band 形態，おび関節円板上下両面の厚みが增加した biconvex 形態） } \\
\text { を関節円板の「変形あり」とした. }\end{array}$ \\
\hline
\end{tabular}


表 2 Classification of arthroscopic findings in the upper joint compartment 上関節腔鏡視所見の分類

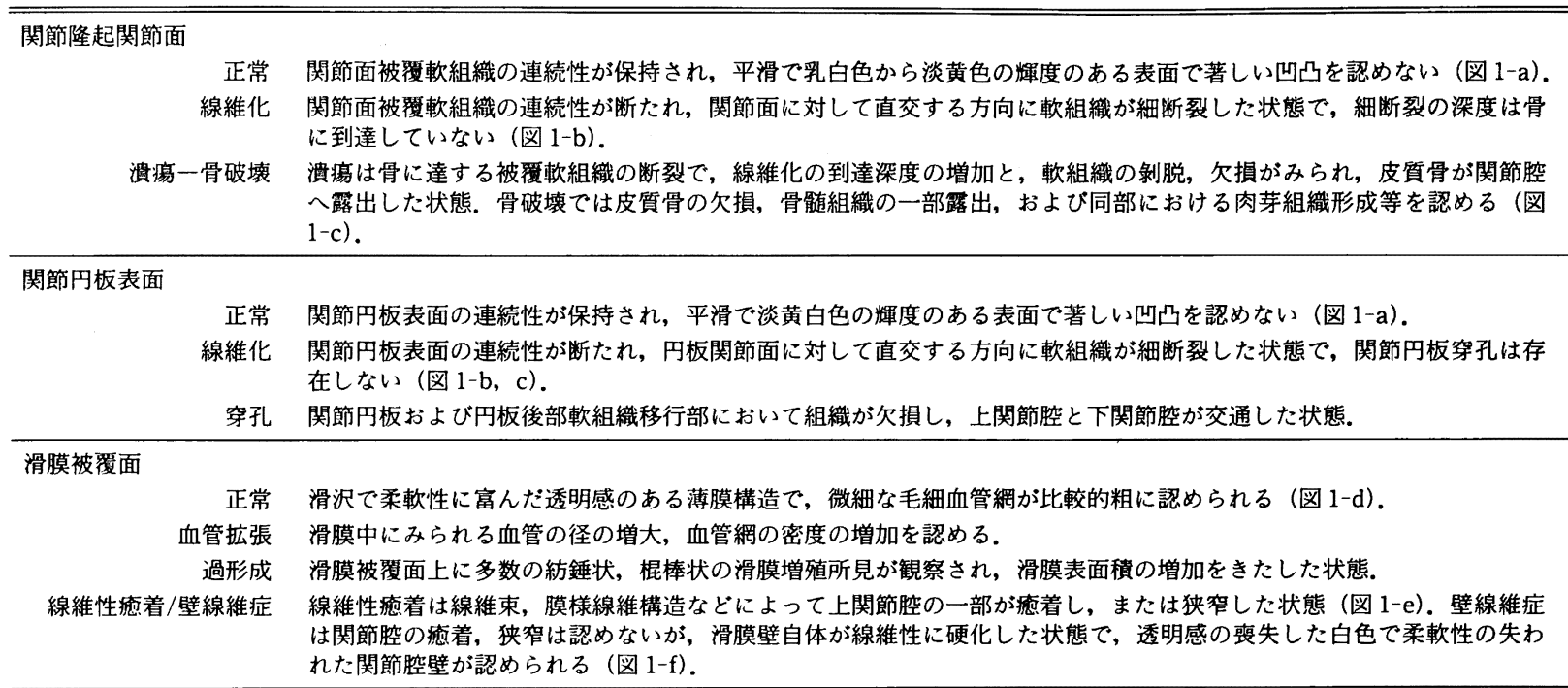

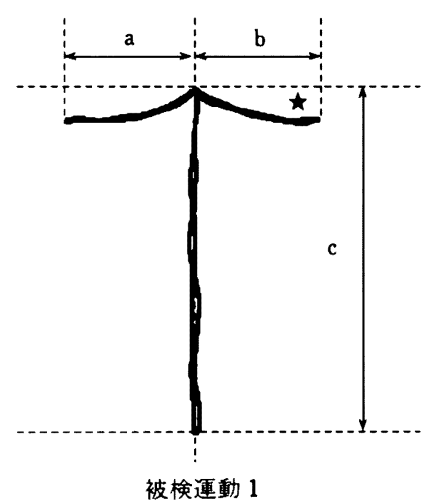

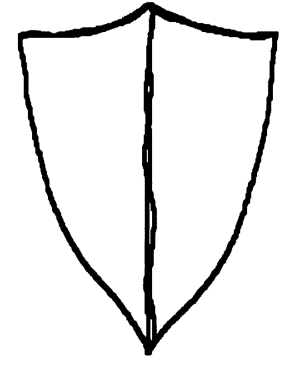

被検運動 2
図 2 Examined mandibular tracking patterns ( $\star$ : Disc displacement side)

$\mathrm{a}$ : Range of lateral movement to the normal side, $\mathrm{b}$ : Range of lateral movement to the disc displacement side, $\mathrm{c}$ : Maximum opening range

被検運動 ( $\star$ : 患側)

$\mathrm{a}$ ：健側側方運動量, b : 患側側方運動量, c : 最大開口量

動を 1 回行わせ,つづいて左右側の最側方咬合位まで接触 滑走を行わせた（運動 1 ）。次に, 咬頭嵌合位から左右側 の最側方咬合位を経て最大開口位に至るまでの側方限界路 上を開口する左右の側方限界運動を行わせ記録した（運動 2 )。すべての運動は咬頭嵌合位より開始し，運動終末位 も咬頭嵌合位とした。

(2) 顎運動所見の評価項目

上記運動路の記録中から，以下の 5 項目についてそれぞ れ計測および評価した。

a 。最大開口量

運動 1 における最大開口時の上下切歯間距離をノギスを 用いて計測した。計測は 3 回行い, 平均值をその個体の代

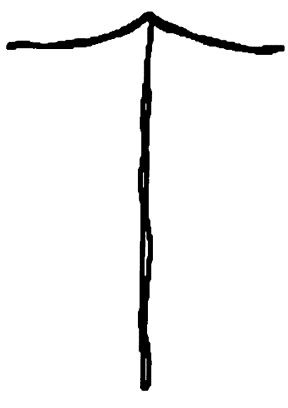

a

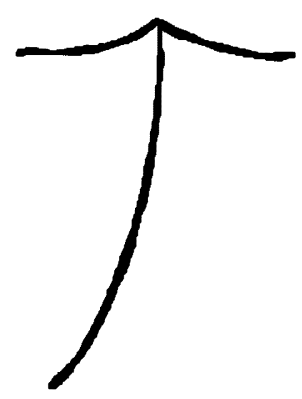

b
图 3 Deviation of the maximum opening position $a:$ No deviation, $b:$ Deviation 最大開口位の偏位 $\mathrm{a}$ ：偏位なし, $\mathrm{b}$ ：偏位あり

表值とした.

b. 側方滑走量

運動 1 において, 健側側方滑走量と患側側方滑走量をノ ギスを用いて計測した. 計測は各 3 回行い平均値をその個 体の代表値とした。

c. 最大開口位の偏位（図 3 ）

運動 1 において，咬頭嵌合位から下ろした重線を正中線 として, 最大開口位が正中線より $5 \mathrm{~mm}$ 以上左右いずれか に偏っているものを偏位ありと分類した.

d. 側方限界運動路の対称性（図 4)

運動 2 において, 咬頭嵌合位と最大開口位を結ぶ直線を 基準として左右側方限界運動路を肉眼的に観察し，その対 称性の有無を判定した.

e. 最大開口位の安定性（図 5 ）

運動 2 において, 左右側方限界運動路上の最大開口位が 一致しないものを不安定とした。これに対し最大開口位が 一致しているものを安定と分類した. 

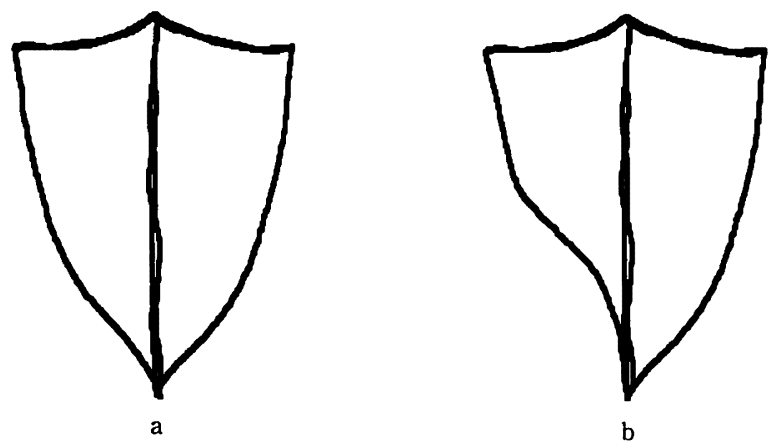

图 4 Symmetry of lateral border movements in frontal view a : Symmetry, b : Asymmetry 側方限界運動路の対称性 $\mathrm{a}$ : 対称, $\mathrm{b}$ : 非対称
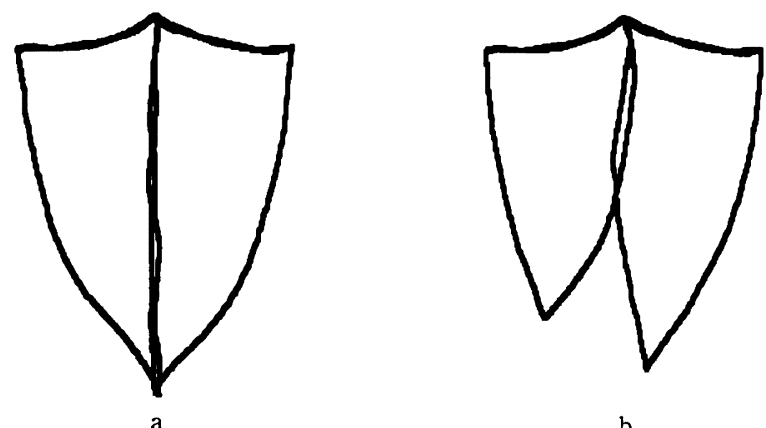

図 5 Stability of the maximum opening position through lateral border movements

a : Stability, b : Instability

最大開口位の安定性

$\mathrm{a}$ : 安定, b : 不安定

\section{3. 各検查所見の比較}

これらの各検查によって得られたデータを相互に比較し たが，その際の統計処理には，Mann-Whitney U 検定, ならびに $2 \times 2$ 分割表による $\chi^{2}$ 検定および Fisher の直接 確率を用いた。

\section{III. 結 果}

\section{1. 対象患者の臨床的病態について}

1） MR 画像所見による分類 (表 3 )

関節円板転位の程度により対象 35 症例を分類したとこ 3，中等度転位が 16 例 $46 \%$ ，高度転位が 19 例 $54 \%$ で， 軽度転位例は認められなかった，中等度転位群 16 例と高 度転位群 19 例では年齢および病悩期間に差はみられず, 関節痛の出現頻度も 81〜 84\% と差はみられなかった。

関節円板変形は 19 例 $54 \%$ にみられ，円板変形の内訳は enlargement of posterior band が 10 例, biconvex が 9 例であった．関節円板変形ありと円板変形なしの群では年 齢および病悩期間に差はみられず，関節痛の出現頻度にも
表 3 Classification of the patients according to MR images MR 画像所見による対象患者の分類

\begin{tabular}{|c|c|c|c|}
\hline & $\begin{array}{l}\text { 年齢 } \\
\text { (SD) }\end{array}$ & $\begin{array}{c}\text { 病悩期間 } \\
\text { (SD) }\end{array}$ & 疼痛あり \\
\hline \multicolumn{4}{|l|}{ 関節円板の転位程度 } \\
\hline 中等度：16 例 & $\begin{array}{l}29.1 \text { 歳 } \\
(11.1)\end{array}$ & $\begin{array}{c}7.6 \text { 力月 } \\
(4.7)\end{array}$ & 13 例 (81\%) \\
\hline 高度：19 例 & $\begin{array}{c}36.3 \text { 葴 } \\
(15.2)\end{array}$ & $\begin{array}{c}6.9 \text { 力月 } \\
(4.8)\end{array}$ & 16 例 (84\%) \\
\hline \multicolumn{4}{|l|}{ 関節円板形態 } \\
\hline 変形なし：16 例 & $\begin{array}{l}31.1 \text { 歳 } \\
(14.4)\end{array}$ & $\begin{array}{c}6.3 \text { 力月 } \\
(4.1)\end{array}$ & 13 例 (81\%) \\
\hline 変形あり：19 例 & $\begin{array}{c}34.5 \text { 歳 } \\
(13.3)\end{array}$ & $\begin{array}{c}8.1 \text { 力月 } \\
(5.1)\end{array}$ & 16 例 $(84 \%)$ \\
\hline
\end{tabular}

表 4 Classification of the patients according to arthroscopic findings in the upper joint compartment 上関節腔関節鏡視所見による対象患者の分類

\begin{tabular}{|c|c|c|c|}
\hline & $\begin{array}{l}\text { 年齢 } \\
\text { (SD) }\end{array}$ & $\begin{array}{c}\text { 病悩期間 } \\
\text { (SD) }\end{array}$ & 疼痛あり \\
\hline \multicolumn{4}{|l|}{ 関節隆起関節面 } \\
\hline 病変なし：20 例 & $\begin{array}{c}29.4 \text { 歲 } \\
(14.4)\end{array}$ & $\begin{array}{c}6.8 \text { 力月 } \\
(4.4)\end{array}$ & 16 例 (80\%) \\
\hline 病変あり：15 例 & $\begin{array}{c}37.8 \text { 歳 } \\
(11.7)\end{array}$ & $\begin{array}{c}7.9 \text { 力月 } \\
(5.1)\end{array}$ & 13 例 (86\%) \\
\hline \multicolumn{4}{|l|}{ 関節円板表面 } \\
\hline 病変なし：25 例 & $\begin{array}{c}29.6 \text { 歳 } \\
(13.9)\end{array}$ & $\begin{array}{c}7.2 \text { 力月 } \\
(4.6)\end{array}$ & 20 例 (80\%) \\
\hline 病変あり：10 例 & $\begin{array}{c}41.2 \text { 歳 } \\
(9.8)\end{array}$ & $\begin{array}{c}7.2 \text { 力月 } \\
(5.1)\end{array}$ & 9 例 (90\%) \\
\hline \multicolumn{4}{|l|}{ 滑膜被覆面 } \\
\hline 病変なし：15 例 & $\begin{array}{c}33.4 \text { 歲 } \\
(14.2)\end{array}$ & $\begin{array}{c}5.9 \text { 力月 } \\
(4.4)\end{array}$ & 12 例 (80\%) \\
\hline 病変あり：20 例 & $\begin{array}{c}32.7 \text { 歳 } \\
(13.8)\end{array}$ & $\begin{array}{c}8.3 \text { 力月 } \\
(4.7)\end{array}$ & 17 例 (85\%) \\
\hline
\end{tabular}

差はみられなかった。

2）関節鏡視所見による分類（表 4）

(1) 関節隆起関節面

関節隆起関節面において線維化ないし潰瘍などの病的所 見が認められたのは 15 例 $43 \%$ であった，病的所見の内訳 は線維化 10 例，潰瘍 5 例であった。残り 20 例 $57 \%$ は正 常であった。病変ありとした 15 例の平均年齢は 37.8 歳, 病変なし群は 29.4 歳であった。年齢, 病悩期間ならびに 関節痛の出現頻度において両群に差はみられなかった。

(2) 関節円板表面

関節円板表面において線維化ないしは穿孔の認められた のは 10 例 29\% であった. 病的所見の内訳は線維化 10 例, 穿孔例はなかった。残り 25 例 $71 \%$ は正常であった。病変 ありとした 10 例の平均年齢は 41.2 歳で病変なし群に比べ 高年歯であった $(p<0.05)$. 病悩期間および関節痛の出 現頻度において両群に差はみられなかった。 
表 5 Comparison of MR images with mandibular tracking patterns MR 画像所見と顎運動所見との対比

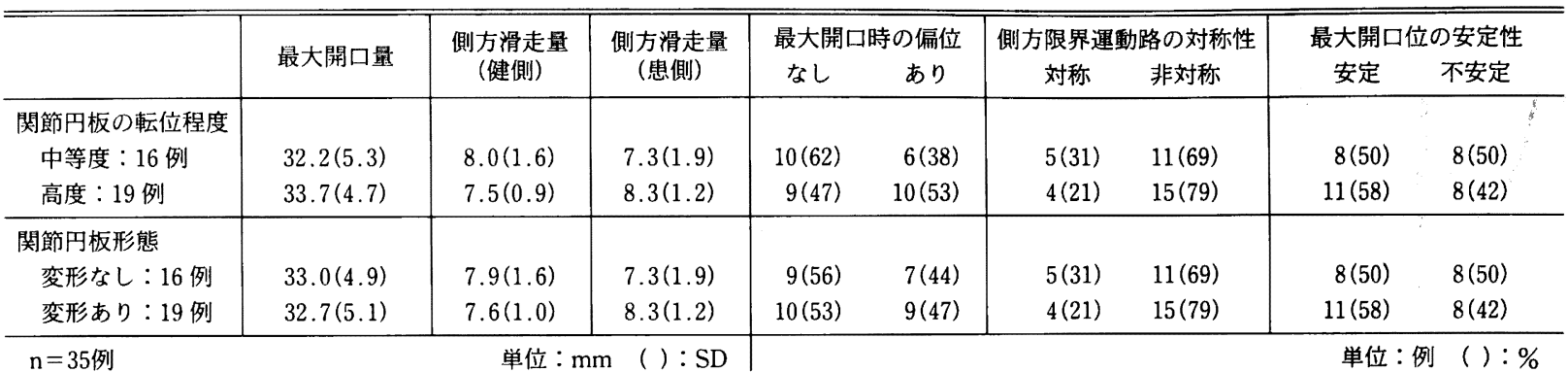

\section{（3）滑膜被覆面}

滑膜被覆面において，病変ありと分類したものは 20 例 $57 \%$ であった，病的所見の内訳は線維性癒着が 11 例，滑 膜壁線維症が 9 例であった。これら線維性病変はすべて上 関節腔前方外側に限局していた。滑膜過形成はなかった。 残り 15 例 $43 \%$ では正常滑膜所見を呈していた．病変あり とした群と病変なし群の間に，年歯，病悩期間ならびに関 節痛の出現頻度に差はみられなかった。

\section{3) 顎運動所見}

対象とした 35 症例の最大開口量の平均は $32.8 \mathrm{~mm}$ （S.D. 4.9）であった．側方滑走量の平均は健側で $7.7 \mathrm{~mm}$ (S.D. 1.3)，患側では $7.9 \mathrm{~mm}$ (S.D. 1.6）であった. 最大 開口位の偏位を認めたものは 16 例 $46 \%$ であった。側方限 界運動路の非対称は 26 例 $74 \%$ に認められた．最大開口位 の不安定を示したものは 16 例 $46 \%$ であった。

\section{MR 画像所見と顎運動所見との対比}

MR 画像所見によって分類された対象群間で䪽運動所見 を比較した結果を表 5 に示した。

1）最大開口量

平均最大開口量は, 関節円板転位の程度が中等度と分類 された群 16 例で $32.2 \mathrm{~mm}$, 高度転位群 19 例では 33.7 $\mathrm{mm}$ であり両群間に差は認められなかった。

関節円板形態に関しては, 円板変形のない群 16 例の平 均最大開口量は $33.0 \mathrm{~mm}$, 円板変形群 19 例では $32.7 \mathrm{~mm}$ で，両群間に差は認められなかった。

\section{2）側方滑走量}

側方滑走量の各群の平均値は, 関節円板転位の程度なら びに円板変形の有無によって差は認められなかった。また 健側と患側との間にも明らかな差は認められなかった。

3）最大開口位の偏位

最大開口位の偏位は関節円板転位の程度による差は認め られず, 中等度転位群の 6 例 $38 \%$, 高度転位群の 10 例 $53 \%$ にみられ。

関節円板変形の有無による差も認められず, 円板変形の ない群の 7 例 $44 \%$, 円板変形群の 9 例 $47 \%$ に最大開口位 の偏位が認められた。
4）側方限界運動路の対称性

側方限界運動路の対称性は関節円板転位の程度による差 は認められず, 中等度転位群の 11 例 $69 \%$, 高度転位群の 15 例 $79 \%$ で非対称所見がみられた。

関節円板変形の有無による差も認められず, 円板変形の ない群の 11 例 $69 \%$, 円板変形群の 15 例 $79 \%$ に非対称所 見が認められた。

5）最大開口位の安定性

最大開口位の安定性は関節円板転位の程度による差は認 められず，中等度転位群の 8 例 $50 \%$, 高度転位群の 8 例 42\%で不安定所見がみられた。

関節円板変形の有無による差も認められず, 円板変形の ない群の 8 例 $50 \%$, 円板変形群の 8 例 $42 \%$ に不安定所見 が認められた。

\section{3. 関節鏡視所見と顎運動所見との対比}

関節鏡視所見によって分類された対象群間で頡運動所見 を比較した結果を表 6 に示した。

1）最大開口量

上関節腔関節鏡視検査によって関節隆起関節面に線維化 および潰瘍などの病的所見が認められ，病変ありとした群 15 例の平均最大開口量は $31.4 \mathrm{~mm}$ で, 病変なし群 20 例 の $31.4 \mathrm{~mm}$ との間に差はなかった。

関節円板表面における線維化を認め, 病変ありとした群 10 例と病変なし群 25 例との間においても差は認められな かった。

滑膜被覆面において線維性癒着および滑膜壁線維症が認 められ，病変ありとした群 20 例の平均最大開口量は 30.4 $\mathrm{mm}$, 病変なし群 15 例では $36.1 \mathrm{~mm}$ で, 両群間には有意 の差が認められた（p<0.05）。

2) 側方滑走量

平均側方滑走量において，関節隆起関節面に病変ありと した群 15 例と病変なし群 20 例との間に差はなかった。

関節円板表面に病変ありとした群 10 例と病変なし群 25 例との間においても差は認められなかった.

滑膜被覆面に病変ありとした群 20 例と病変なし群 15 例 との間に差は認められなかった。 
表 6 Comparison of arthroscopic findings in the upper joint compartment with mandibular tracking patterns 上関節腔関節鏡視所見と頴運動所見との対比

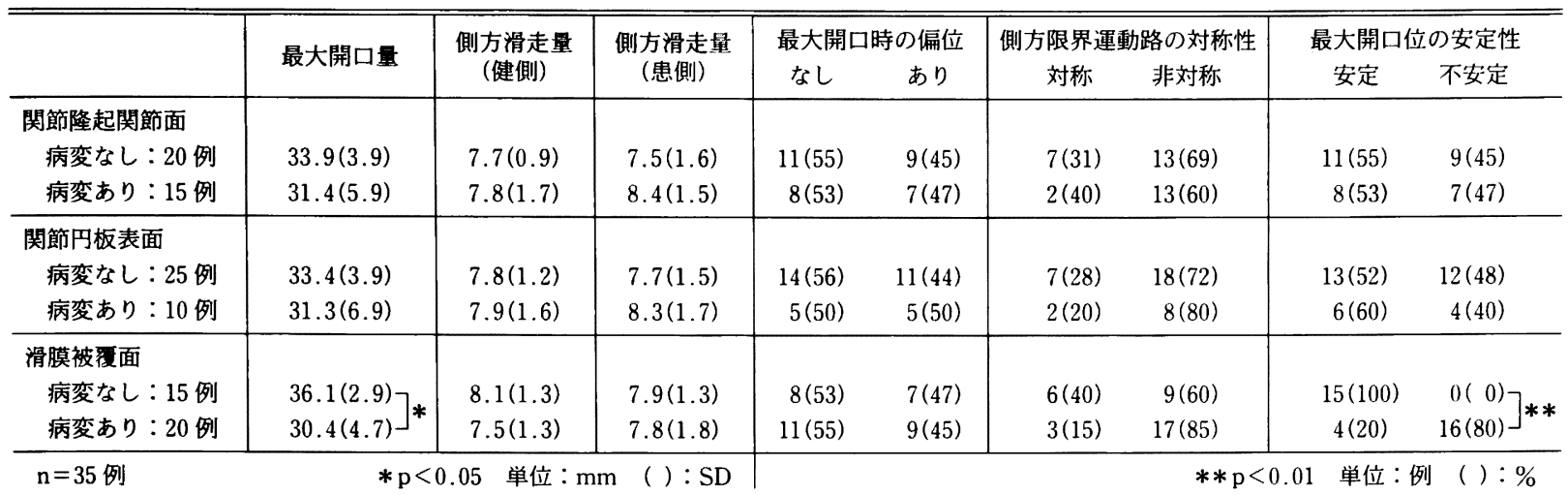

すべての鏡視部位において，側方滑走量の平均は健側と 患側との間で差はなかった。

3）最大開口位の偏位

関節隆起関節面の病変の有無によって, 最大開口位の偏 位の出現頻度に差は認められなかった。

関節円板表面の病変の有無によって, 最大開口位の偏位 の出現頻度に差は認められなかった。

滑膜被覆面の病変の有無によって, 最大開口位の偏位の 出現頻度に差は認められなかった。

4）側方限界運動路の対称性

関節隆起関節面の病変の有無によって, 非対称所見の出 現頻度に差は認められなかった。

関節円板表面の病変の有無によって, 非対称所見の出現 頻度に差は認められなかった。

滑膜被覆面の病変の有無によって, 非対称所見の出現頻 度に差は認められなかった。

5）最大開口位の安定性

関節隆起関節面の病変の有無によって, 不安定所見の出 現頻度に差は認められなかった。

関節円板表面の病変の有無によって，不安定所見の出現 頻度に差は認められなかった。

滑膜被覆面において線維性癒着および滑膜壁線維症が認 められ, 病変ありとした群において不安定所見が高頻度に 認められた $(p<0.01)$.

\section{IV. 考 察}

下䪽の運動制限と顎関節内障との関係は, これまでに顎 運動から買関節内の病態を推定する報告がなされてい $ろ^{14 \sim 17)}$ か，下顎運動に多くの因子が複雑に関与している ことから明快な結論が得られないまま今日に至っている. しかし，下顎運動制限の寄与因子と考えられる顎関節内の 病態と対応する顎運動との関連性を検討することは, 異常 運動の原因の追究やその解明に至るまでの一段階として有
意義と思われる。

以上のような背景から, 本研究では腔内病変と下顎運動 経路との関連を明らかにすることを目的として，顎関節内 障と診断した患者群における腔内病変の存在と顎運動所見 との関連性を対比的に検討した。

\section{1. 研究方法について}

1) 研究対象について

顎関節は他の関節にはみられない複雑な運動様相を示 す。それは，左右側の下顎頭は下顎骨体により連結されて おり，左右側の下顎頭は独立した運動を行えず，一側の顎 関節の運動が他側の関節運動に直接的な影響を与えるため である。このことが顎運動を評価する上で大きな問題と なってくる，そこで，本研究では片側性の非復位性関節円 板前方転位症例のみを対象とした。

また，䫟関節腔内の病変が顎運動に及ほす影響を検討す るにあたり，強度の筋痛を有するものは除外した。これは 運動制限の原因を顎関節に起因するものに限定するためで ある。

2） MR 画像検査について

MR 画像検査は関節円板の描出に高い診断精度を有する 画像検査法で ${ }^{18)}$ ，下顎頭および側頭骨に対する関節円板の 位置・形態を知ることができる，また，関節腔造影検査と 比べ，患者への侵襲が全くないこと，関節腔を造影剤に よって拡張することなく自然な状態で観察できる利点を有 している ${ }^{19)}$. 以上のような背景から，本研究において関節 円板の位置・形態を検出するにあたり MR 画像検査を実施 した.

3） 関節鏡視検査について

腔内病変の検出には関節腔造影検査よりも関節鏡視法の 方が有効であるため 20)，これを用いた，関節鏡視法は関節 腔内を内視鏡によって直接観察を行う検査法で，顎関節で は主に上関節腔において臨床的に応用されてきており，本 研究においても上関節腔について実施した。また，上関節 
腔鏡視法によって得られた所見を重要視した背景は，上関 節腔は顎関節運動において主に滑走運動に関与し，下顎運 動経路に及ほす影響が大きいことによっている21．また顎 関節の関節面変性すなわち变形性関節症は下顎頭関節面に 比較して側頭骨関節面において高頻度であり，下顎頭では むしろ関節面表層は正常であるが下顎頭外形の変化をきた すいわゆる DIF（deviation in form）の頻度が高いことに よっている22,23).

4）顎運動検査について

今回, 顎運動経路の評価についてサホンビジトレーナー Model 3 を用い, 切歯点描記による限界運動によって検討 した。碩限界運動は咀嚼運動とは異なり，機能的意義は 少ないものの, 各個体における固有の運動能力を表現する ことから ${ }^{13)}$, 関節内病変との対比に有効と考えた。また切 歯点描記による正常者の下顎運動経路については, ほほ全 容が明らかにされており ${ }^{13.24)}$, さらに最近では顎関節内障 患者についても復位性, 非復位性の両者についてデータが 蓄積されていることから ${ }^{7,25,26)} こ の$ 運動を本研究の対象と した。切歯点の限界運動路の異常は側方限界運動路の前頭 面投影像にもっとも顕著に現れるという古屋 ${ }^{13)}$ の報告や, 患側への偏位など異常顎運動所見は前頭面投影として得や

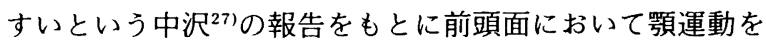
評価した。

しかし，本検查法は一定の条件で装置を患者に装着する ことが困難で, このため精度上の誤差を完全には排除でき ない．また 2 次元表示のみが可能で，立体的な同時観察は 不可能である点も欠点となるが, 本研究のごとき患者対象 研究では, これら欠点を包含した上でも, 臨床の場におい て使用できる簡便さと簡易検査としての応用性の広さがあ り，これを重視した，今後臨床の場において使用可能な簡 便な装置による下䫟限界運動の計測, 特に 3 次元化が可能 となればささらに詳細にまた多数例についても関節内病変 との関連を追究できるであろう。

\section{2. 関節円板の位置・形態と頡運動との関連性について}

これまでに関節円板の位置・形態が顎運動に及ほす影響 について, 転位が高度で関節円板の変形を認めた症例では 開口量が増加する傾向にあったという報告6.99 や，転位の 程度が高度でも円板変形がないと明らかな運動制限を呈す るという報告"がある。しかし今回の結果からは，MR画 像所見から得られた関節円板の転位の程度および変形の有 無によって, 対応する顎運動所見に明らかな差は認められ ず,これまでの報告とは異なる結果になった。

これまで運動制限の原因として関節円板の前方転位があ げられ, その程度や形態と運動制限との関係が追究されて きた。 今回の結果から腔内病変が運動制限に関与している ことがわかり，現在では関節円板の復位を得なくても十分 な下顎頭の運動量が得られることもわかっている.これら
のことから関節円板の前方転位は運動制限の 1 因子ではあ るが，その主体をなすとは考えにくいことが示唆された. しかし関節円板の転位の程度や形態に関する情報は, 治療 を進めていくにあたり重要であり ${ }^{20)}$, 特に円板整位の可能 性を評価する上で必要不可欠である。 また，今回の対象の 関節円板の転位方向はすべて前方であったが，内外側的な 関節円板の転位が強い運動制限を示すとの報告もあり ${ }^{28)}$, 今後の検討課題と考えられる.

\section{3. 腔内病変と顎運動との関連性について}

1）滑膜被覆面における病変について

今回の結果から, 上関節腔関節鏡視検査によって, 関節 非荷重負担部である滑膜被覆面, 特に関節腔前方外側部に おける線維性㾍着および滑膜壁線維症が検出された症例群 では, 有意な最大開口量の減少 $(\mathrm{p}<0.05)$, ならびに最 大開口位の不安定所見の有意の増加 $(\mathrm{p}<0.01)$ が明らか となった (図 6,7: 臨床例).

䫕関節内障すなわち関節円板の前方転位に伴って上関節 腔内に線維性癒着病変が出現することは過去においても報 告されており 20,29 -33), この線維性癒着病変は病理学的に はコラーゲン線維に富む細胞成分の乏しい線維構造である ことが確認されている ${ }^{344}$. また, 上関節腔の線維性痹着病 変および関節包の線維化は前方外側滑膜壁に高頻度に発生 することも報告されている ${ }^{31,32,35)}$.これら線維性痹着病変 と顎関節機能との関連性について Murakami ら ${ }^{36}$ ) は頡関 節内障患者に対する質問表と関節鏡視所見の対比から, 上 関節腔内の線維性癒着病変は開口障害の 1 因子であること を指摘している.

今回の結果では滑膜被覆面において, 病変ありと分類し たものは 20 例 $57 \%$ であった。病的所見の内訳は線維性瘑 着が 11 例, 滑膜壁線維症が 9 例であった。しかもこれら 線維性病変はすべて上関節腔前方外側に限局していた。

これら滑膜被覆面の病変すなわち線維性痹着および滑膜 壁線維症の存在と最大開口位の不安定所見との間には関連 性が認められた。下村 ${ }^{25}$, 野瀬ら ${ }^{26)}$, 宮本ら 位の不安定所見を, 片側性非復位性関節円板前方転位症例 の特徵的な靧運動所見として報告している。この所見に関 して, 下村 ${ }^{25}$ は, 関節円板の内方転位を合併するか, ある いは下顎頭の関節円板との協調失調を推測できるものと述 べている．また野瀬ら ${ }^{26)}$ は，患側の下顎頭・関節円板の協 調失調によるものか, あるいは反対側によるものかは特定 できなかったとし,さらに最大開口位の一致が約半数に認 められたことから関節内の病態は単一ではなく, 関節円板 の前方転位による患側下顎頭の運動制限の程度や様式が多 様であることを示唆している.

これら最大開口位における不安定所見を記載した過去の 報告では, 関節円板転位の病態との関連にのみ言及してお $\eta$, 関節腔内の病変との関連については検討していない. 
本報告において不安定所見を呈した症例のすべてに滑膜被 覆面の病的関節鏡視所見すなわち線維性疮着ならびに滑膜 壁線維症を認めた.これら病的関節鏡視所見と最大開口位 の不安定所見との関連のメカニズムについては, 腔内病変 によって運動制限が生じたのか, 運動制限によって腔内病 変が生じたのか, 原因と結果が明確にされてはいないもの の, 上関節腔の線維性癒着および滑膜壁線維症により関節 円板の可動性が減少することによって引き起こされる下顎 頭の回転および滑走運動の協調失調と考えられる.

過去の報告が指摘するように関節円板転位の存在が最大 開口位の不安定所見の原因と考えるならば，円板転位によ る機械的な下䝷頭滑走障害が，2次的に上関節腔前方外側 の線維性変化の発生を促しているとも考えられよう。しか し今回の研究結果から, 非復位性関節円板前方転位例にお ける MR 画像所見上の関節円板転位の程度, 関節円板変 形の有無は, 開口障害の程度, 最大開口位の不安定所見の 出現頻度に関連がないことが明らかとなった，一方，滑膜 被覆面の線維性病変は, その発生由来の如何は別に, 結果 として開口障害の程度および最大開口位の不安定所見に関 与する因子であることが明らかになった。

今回の検索では上関節腔における関節鏡視検査によって 得た所見によって顎運動との対比を行ったが，下関節腔に おいても線維性癒着病変が出現することが, 肉眼病理学的 ならびに関節鏡視検査によって確認されていることか $ら^{37)}$, 今後検討しなくてはならない課題と考えられる.

2）関節隆起関節面，関節円板表面の病変について 変形性関節症は関節面被覆軟骨の変性破壊と, これに伴 j 2 次的骨軟骨の増殖性変化と定義され ${ }^{38)}$, 顎関節におい ても側頭骨関節面および下顎頭関節面において発生するこ とが肉眼病理学的に明らかにされている22,39,40). 関節円板 の転位に伴って荷重負担部である関節面すなわち側頭骨関 節隆起関節面, 下頡頭関節面ならびに対面する関節円板表 面の変性所見が増加することが報告されている41,42).

MR 画像検査による関節円板転位の程度および形態変化 の有無と上関節腔関節鏡視検査による関節隆起関節面なら びに関節円板表面の変性所見の出現頻度との関連性につい $て$, enlargement of posterior band および biconvex など の関節円板変形が認められる症例群では関節隆起関節面な らびに関節円板表面の変形性関節症所見が有意に増加する ことが報告されている ${ }^{2,43)}$. 相対する関節面間における変 性の進行は, 生体力学的な観点から, 関節表面の運動時摩 擦抵抗の増大を引き起こすとされている(4). 枵関節の変形 性関節症における関節面の生体力学的な特性に関する報告 はいまだみられないが，凌関節をはじめとする他関節と同 様に運動時摩擦抵抗の増加などの変化が生じていると考え られる．以上のような背景から非復位性関節円板前方転位 例の関節面変性について上関節腔関節鏡視検査を行い, こ れらの所見と顎運動所見との対比を試みた。
今回の結果から，関節隆起関節面において線維化ないし 潰崵などの変性所見が認められたものは 15 例 $43 \%$ で, 病 的所見の内訳は線維化 10 例, 潰晹 5 例であった. 残り 20 例 $57 \%$ は正常であった。 また関節円板表面において変性 所見とした線維化ないしは穿孔の認められたものは 10 例 $29 \%$ であった。病的所見の内訳は線維化 10 例, 穿孔例は なかった. 残り 25 例 $71 \%$ は正常であった。しかし関節面 の変性変化の出現した症例群と変性の認められない群との 間の顎運動所見には差は認められなかった。

関節面の変形性関節症所見の出現頻度とその程度は, 関 節円板転位の出現頻度とともに，年齢が増加するに従って 高度となることが報告されている ${ }^{45)}$. 今回の検索対象と なった症例群の平均年齢は 32.9 歳と比較的若く, 変性所 見の進行の程度は初期変性所見である関節隆起関節面の線 維化，ならびに関節円板表面の線維化がほとんどであり， 高度な変性所見は少ない傾向にあった。すなわち, 今回の 結果から, 顎運動経路などが表現する顎関節の動態所見上 に, 初期の変形性関節症病変の存在を反映する所見は得難 いことが示唆された. また，今後進行した関節面変性すな わち変形性関節症が顎関節機能に及ほすす影響を検索する必 要性が示された。

\section{V. 結 論}

片側性の非復位性関節円板前方転位と診断した 35 例の 顎関節内障患者を対象とし, 関節円板転位の程度, 円板形 態変化の有無をMR 画像上で分類し，さらに同対象に対 して上関節腔関節鏡視検査を行い, 䪽関節腔内病変を荷重 負担部である関節隆起関節面および関節円板表面, ならび に非荷重負担部である滑膜被覆面についてそれぞれ所見を 採取した。これらの結果を対応する顎運動所見と対比し， 相互の関連性について検討し，以下の結論を得た。

1. 対象とした 35 症例の顎運動所見では, 最大開口量 の平均は $32.9 \mathrm{~mm}$ (S.D. 4.9), 健側側方滑走量は 7.7 $\mathrm{mm}$ (S.D. 1.3), 患側側方滑走量は $7.9 \mathrm{~mm}$ (S.D. 1.6) であった。最大開口位の偏位が $46 \%$, 側方限界運動路の 非対称が $74 \%$ ，最大開口位の不安定が $46 \%$ に認められ た。

2. MR 画像における関節円板の転位の程度，ならびに 円板変形の有無によって, 対応する顎運動所見に明らかな 差は認められなかった。

3. 上関節腔関節鏡視所見と対応する顎運動所見から， 上関節腔の非荷重負担部である前方外側部滑膜被覆面の線 維性病変は下顎限界運動路の制限に関与する因子と考えら れ, 線維性癒着, ないしは滑膜壁線維症が存在する症例群 では, 最大開口量の減少 $(p<0.05)$, 最大開口位の不安 定所見の増加（p<0.01）がみられた. しかし荷重負担部 である関節隆起関節面わよび関節円板表面の初期変形性関 
節症所見と，顎運動所見との間に関連性は認められなかっ た.

稿を終えるにあたり，終始ご愁篤なるご指導とご校閲を賜りました 本学歯学部歯科補緅学第二講座福島俊士教授に深く感謝の意をささげ るとともに，本研究にご助言ご校閲をいただいた本学歯学部第一口腔 外科学教室瀨戸晥一教授, 本学歯学部歯科補綴学第三講座細井紀雄教 授に拝謝いたします。また終始ご指導いただきました横浜労災病院歯 科口腔外科近藤寿郎部長に心より感謝の意を表します.さらに本研究 の遂行にあたり，有益なご助言をいただきました本学歯学部歯科放射 線学教室小林 然助教授に心からの謝意を表すとともに, 横浜労災病 院歯科口腔外科の先生およびスタッフの方々, 本学歯科放射線学教室 研究員諸兄, 本学附属病院レントゲン室の皆様ならびに歯科補緅学第 二講座教室員，大学院学兄に梁く感謝いたします。最後に本研究の主 旨をご理解いただきご協力くださいした患者の皆様に厚く御礼申し 上げます。

なお, 本研究の要旨の一部は, 平成 6 年度日本補緅歯科学会関東支 部学術大会（1995 年 2 月 10 日, 東京）ならびに第 94 回日本補緅歯 科学会学術大会（1995 年 10 月 27, 28 日, 岡山）において発表した.

\section{文献}

1) Farrar WB. Characteristics of the condylar path in internal derangements of the TMJ. J Prosthet Dent 39:319-323, 1978.

2) Farrar WB, McCarty WL. Inferior joint space arthrography and characteristics of condylar paths in internal derangements of the TMJ. J Prosthet Dent 41:548-555, 1979.

3) Wilkes $\mathrm{CH}$. Structural and functional alterations of the temporomandibular joint. Northwest Dent $57: 287-294,1978$.

4) Wilkes $\mathrm{CH}$. Arthrography of the temporomandibular joint : in patients with the TMJ pain-dysfunction syndrome. Minn Med 61:645-652, 1978.

5) Isberg.Holm AM, Westesson P.L. Movement of disc and condyle in temporomandibular joints with clicking : An arthrographic and cineradiographic study on autopsy specimens. Acta Odontol Scand 40:151-164, 1982.

6) Roberts CA, Katzberg RW, Tallents RH et al. Correlation of clinical parameters to the arthrographic depiction of tempor omandibular joint internal derangements. Oral Surg Oral Med Oral Pathol 66:32-36, 1988.

7）宮本 諭，小川 匠，細田 裕ほか。顎関節内障患者の顎運動 と MRI 所見の比較検討一関節円板前方転位例について一。補緅 誌 $37: 1283-1293,1993$.

8）福島俊士，小林 柏. 顎機能異常の診断一MRI を導入して一. 補緅臨床 $27: 701-711,1994$

9) Holmlund A, Hellsing G. Arthroscopy of the temporomandibular joint : occurrence and location of osteoarthrosis and synovitis in a patient material. Int J Oral Maxillofac Surg $17: 36-40,1988$

10) Holmlund A, Hellsing G. Arthroscopy of the temporomandibular joint: A comparative study of arthroscopic and tomographic findings. Int J Oral Maxillofac Surg 17:128133, 1988.

11) Westesson P.L, Rolin M. Diagnostic accuracy of doublecontrast arthrotomography of the temporomandibular joint : Correlation with postmortem morphology. AJR 143 : $655-660,1984$

12）近藤寿郎，重井和利，芳賀満理ほか。買関節内障の変形性関節 症所見に対する画像診断と関節鏡視との比較検討．日口科誌 $44: 628-638,1995$

13）古屋良一. 䪽口腔系の機能に異常を有する者の下顎運動の研 究. 補緅誌 $18: 221-245,1974$.

14) Bates RE, Welsch BB, Stewart CM. Temporomandibular joint disk position as determined by simple recorder. J Prosthet Dent $56: 221-225,1986$.

15) Mauderli AP, Lundeen HC. Simplified condylar movement recorders for analyzing TMJ derangements. J Craniomandib Pract 4:207-212, 1986.

16) Mauderli AP, Lundeen HC, Loughner B. Condylar movement recordings for analyzing TMJ derangements. J Craniomandib Disord Facial Oral Pain 2 : 119-127, 1988

17）和嶋浩一, 野本種邦，名波智章ほか. 非接触下䫛運動測定によ る顎関節内障における関節円板の動態検查. 日枵誌 4:358369, 1992.

18) Tasaki MM, Westesson P-L. Temporomandibular joint: Diagnostic accuracy with sagittal and coronal MR imaging. Radiology 186: 723-729, 1993.

19) Katzberg RW. Temporomandibular joint imaging. Radiology $170: 297-307,1989$.

20) Liedberg J, Westesson P.L. Diagnostic accuracy of upper compartment arthroscopy of the temporomandibular joint : Correlation with postmortem morphology. Oral Surg Oral Med Oral Pathol $62: 618-624,1986$.

21) Rees LA. The structure and function of the mandibular joint. Br Dent J 96 : 125-133, 1954

22) Hansson $T$, Öberg $T$. Arthrosis and deviation in form in the temporomandibular joint : A macroscopic study on a human autopsy material. Acta Odontol Scand $35: 167-174,1977$.

23) Hansson T, Nordström B. Thickness of the soft tissue layers and articular disk in temporomandibular joints with deviations in form. Acta Odontol Scand $35: 281-288,1977$.

24）鈴木 温. ディジタル方式下顎運動測定器による下䫕限界運動 の 6 自由度解析. 補綴誌 $31: 712-725,1987$.

25）下村哲也．復位を伴わない頻関節円板前方転位例における治療 前後の顎運動に関する研究. 粜科学報 91：999-1029, 1991.

26）野瀬將洋，村上賢一郎，横山忠明ほか。枵関節内障クローズド ロックにおける下䫟運動解析に関する研究. 日口科誌 $39: 898-$ 906, 1990.

27）中沢勝宏。顎関節症における下䫟運動の分析. 歯科学報 74 ： 277-311, 1974.

28) Katzberg RW, Westesson P-L, Tallents RH et al. Temporomandibular joint : MR assessment of rotational and sideways disk displacements. Radiology $169: 741-748,1988$.

29) Hellsing G, Holmlund A, Nordenram $\AA$ et al. Arthroscopy of 
the temporomandibular joint: Examination of 2 patients with suspected disk derangement. Int J Oral Surg $13: 69-74$, 1984.

30) Sanders B. Arthroscopic surgery of the temporomandibular joint : Treatment of internal derangement with persistent closed lock. Oral Surg Oral Med Oral Pathol $62: 361-372$, 1986.

31）近藤寿郎，小林 警. 額関節上関節腔内線維性痔着病変の診断 と治療：その 2 関節内視鏡所見と関節鏡視下剩離授動術. 鶴 見歯学 $15: 173-181,1989$.

32）瀬上夏樹，村上賢一郎，藤村和磨ほか。顎関節内障クロースド ロック症例の関節鏡視所見. 日ロ科誌 $38: 857-869,1989$.

33）近藤寿郎，小林 㯺，鹿島隆正ほか. 額関節上関節腔鏡視下剶 離授動術の術後成績に関する臨床的検討. 日口科誌 $40: 249$ 262, 1991.

34) Kurita K, Bronstein SL, Westesson P.L et al. Arthroscopic diagnosis of perforation and adhesions of the temporomandibular joint: Correlation with postmortem morphology. Oral Surg Oral Med Oral Pathol 68:130-134, 1989.

35）瀬上夏樹，村上留一郎，藤村和磨ほか．額関節内障にみられる 線維性疮着病変一第一報，Pseudowall の関節鏡視所見一。 日 額誌 $2: 326-332,1990$.

36) Murakami K, Segami N, Moriya $Y$ et al. Correlation between pain and dysfunction and intra-articular adhesions in patients with internal derangement of the temporomandibular joint. J Oral Maxillofac Surg $50: 705-708,1992$.

37) Kondoh T, Westesson P-L. Diagnostic accuracy of temporomandibular joint lower-compartment arthroscopy using an ultrathin arthroscope : A postmortem study. J Oral Maxil. lofac Surg $48: 619-626,1991$.

38）山本 真. 定義. 山本 真, 杉岡洋一, 二八宮節夫編, 変形性 関節症のすへて 3-4, 東京 : 医菌薬出版, 1982.

39) Öberg T, Carlsson GE, Fajers C-M. The temporomandibular joint : A morphologic study on a human autopsy material. Acta Odontol Scand $29: 349-384,1971$.

40) Axelsson S, Fitins D, Hellsing G et al. Arthrotic changes and deviation in form of temporomandibular joint : an autopsy study. Swed Dent J $11: 195-200,1987$.

41) Westesson P-L, Rohlin M. Internal derangement related to osteoarthrosis in temporomandibular joint. Oral Surg 57 : 17-22, 1984.

42) DE Bont LGH, Boering G, Liem RSB et al. Osteoarthritis and internal derangement of the temporomandibular joint : A light microscopic study. J Oral Maxillofac Surg $44: 634$ 643, 1986.

43) Kondoh T, Seto K. MRI and arthroscopic findings in patients with internal derangement of the temporomandibular joint. Dent Jpn $29: 65-72,1992$.

44) Woo SL-Y, Kwan MK, Coutts RD et al. Biomechanical considerations. In : Moskowitz RW, Goldberg VM, Mankin HJ et al editors, Osteoarthritis : Diagnosis and medical/surgical management 191-211, Philadelphia : WB Saunders Co, 1992.

45) Pereira FJ, Lundh H, Westesson P.L. Morphologic changes in the temporomandibular joint in different age groups: An autopsy investigation. Oral Surg Oral Med Oral Pathol 78 : 279-287, 1994.

\section{一図の説明一}

図 1 Arthroscopic findings of the upper joint compartment

$\mathrm{a}$ : Articular surface of the temporal bone and disc surface in normal condition, $\mathrm{b}:$ Fibrosing of the articular surface of the temporal bone and the disc surface, $c$ : Ulceration of the articular surface of the temporal bone and fibrosing of the disc surface, $d:$ Normal synovial lining, $e:$ Fibrous adhesion of the synovial lining, $f:$ Fibrosis of the synovial wall

上関節閘関節鏡視所見

$\mathrm{a}$ : 正常関節隆起関節面および正常関節円板表面， b : 関節隆起関節面わよび関節円板表面の線維化，c：関節隆起関節面の謴瘍化および関 節円板表面の線維化, d : 正常滑膜被覆面, e : 滑膜被覆面の線維性痹着, f : 滑膜壁線維症

图 6 A case without intra-articular changes

a : MR images (Degree of disc displacement : severe, disc configuration : biconvex), b : Arthroscopic findings (Normal synovial lining at the anterolateral portion of the upper joint compartment), $c:$ Mandibular tracking pattern ( $\star$ : Disc displacement side) 関節腔内病変を認めない症例

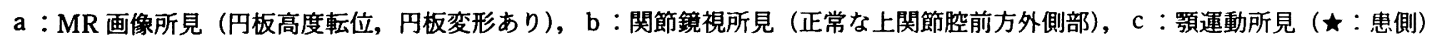

图 7 A case with intra-articular changes

a : MR images (Degree of disc displacement : severe, disc configuration : biconvex), b : Arthroscopic findings (Fibrosis of synovial wall at the anterolateral portion of the upper joint compartment), $c:$ Mandibular tracking pattern ( $\star$ : Disc displacement side) 関節腔内病変が認められる症例

$\mathrm{a} ：$ MR 画像所見 (円板高度転位, 円板変形あり), b : 関節鏡視所見 (上関節腔前方外側部の滑膜壁線維症が認められる)，c：頞運動所見 ( $\star$ : 患側) 

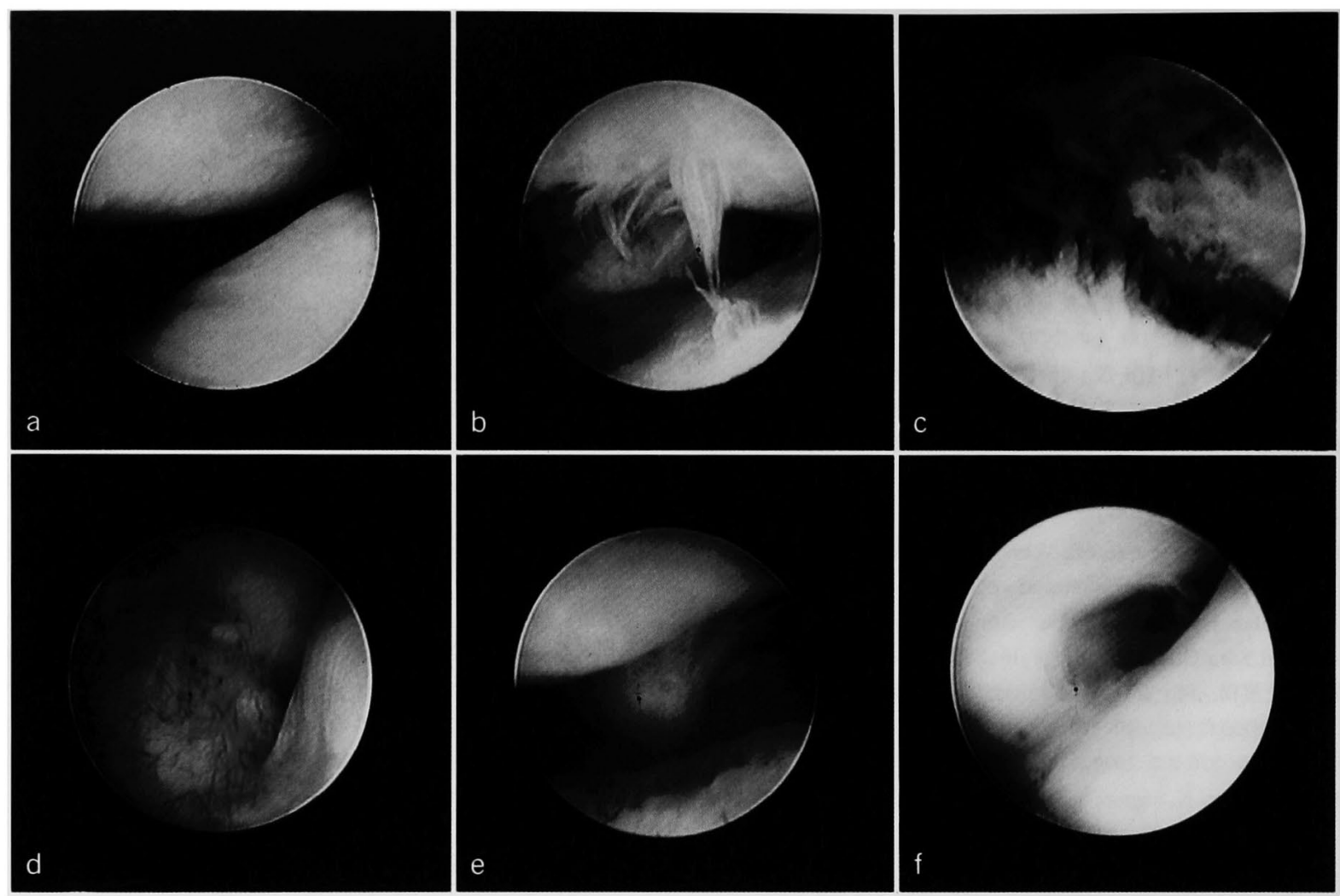

図 1
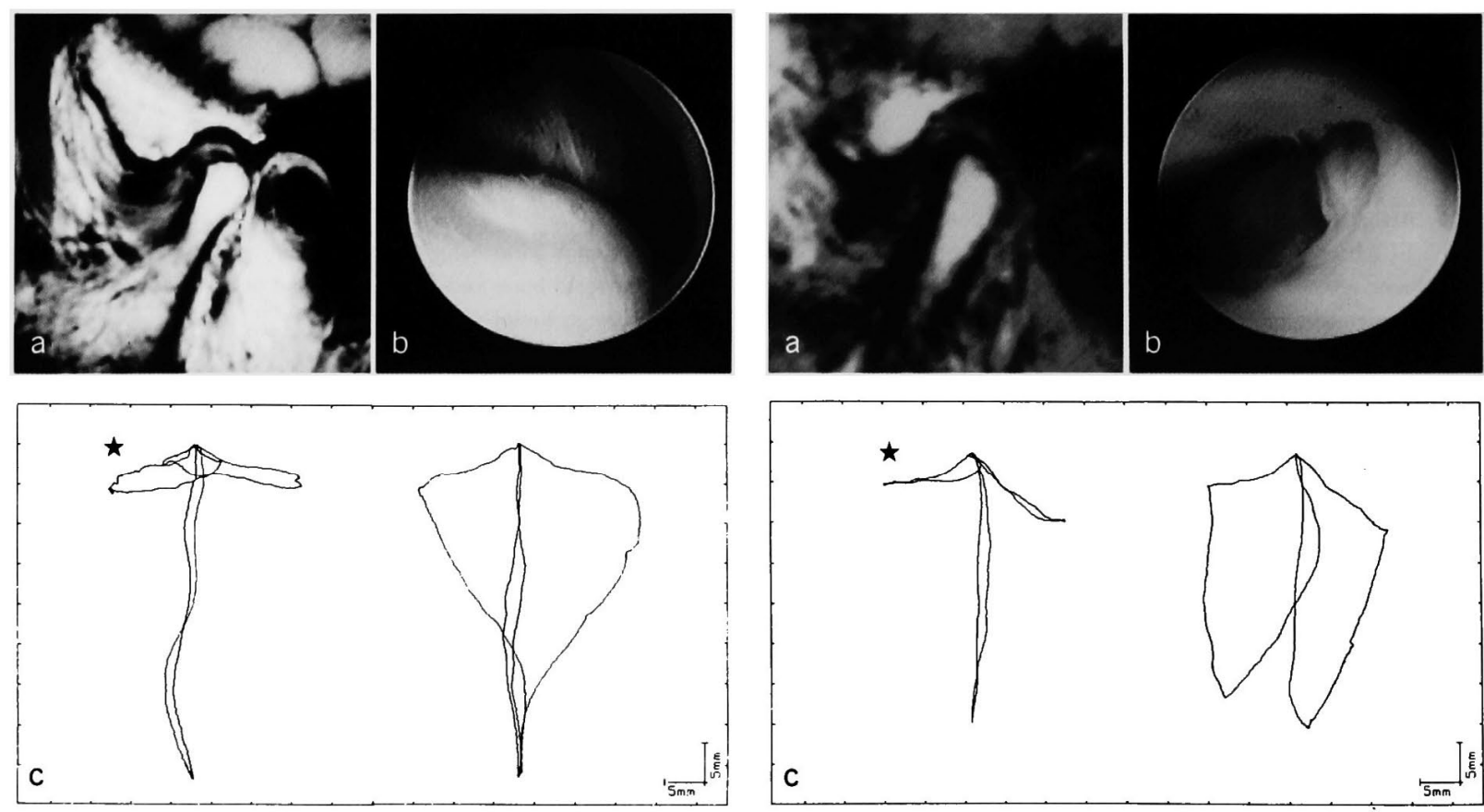

図 6

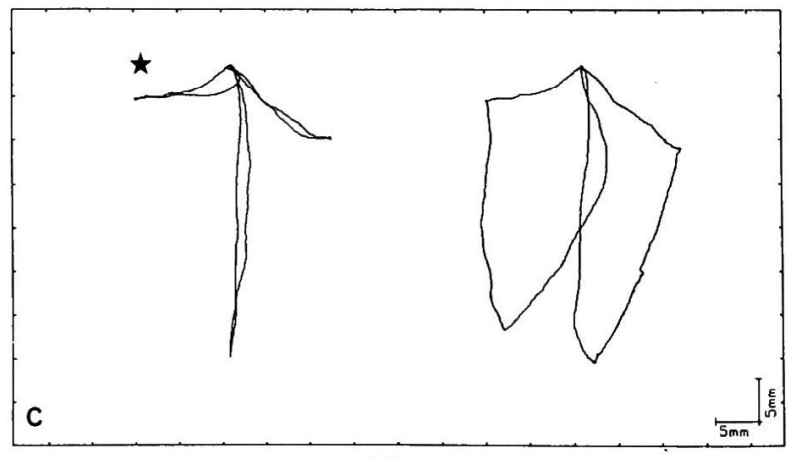

図 7 